\title{
İnternet Erişim Özgürlüğünün Kısıtlanması: Türkiye Üzerine Bir Değerlendirme
}

\author{
Restrictions of Internet Access Freedom: \\ An Evaluation Study of Turkey
}

\author{
Türkay HENKOĞLU* ve Bülent YILMAZ**
}

\begin{abstract}
Öz
Türkiye'de internet erişim engellemeleri ve sansür algısında farklılıkların bulunması, bu konudaki literatüre de yansımaktadır. Literatürde, sınırsız internet erişim özgürlüğü isteyen, 5651 Sayılı Kanun'u eleştiren ve kaldırılması gerektiğini savunan ya da tüm filtreleme ve erişim engellemelerini sansür uygulaması olarak nitelendiren birçok yayın yer almaktadır. Bu çalışmada, Türkiye'de internet erişim özgürlüğünün kısıtlanmasına neden olan uygulamaların, mevcut hukuksal düzenlemeler çerçevesinde değerlendirilmesi amaçlanmıştır. Önceki çalışmalardan farklı olarak, mevzuat, uygulama ve alınan kararlar arasındaki ilişki ayrıntılı olarak incelenmiş, zararlı içeriğe sahip olduğu gerekçesiyle internet sitelerinin erişime kapatılmasının ne kadar başarılı olduğuna yanıt aranmış ve erişim engellemelerinin amacına ulaşabilmesi için neler yapılması gerektiği konusunda önerilerde bulunulmuştur. Ayrıca, alternatif yöntemler aracılığıyla erişime kapatılan sitelere nasıl kolayca erişim sağlanabildiğine dikkat çekilmiş ve bu durumun bilgi erişim özgürlüğü kapsamında hukuksal değerlendirmesi yapılmıştır. Literatürde yer alan eleştirilerin geçerliği hukuksal düzenlemeler, alınan erişim engelleme kararları, Yargıtay kararları ve uygulama sonucunda amaçlanan hedefe ulaşılabilme durumu irdelenerek yeniden değerlendirilmiştir. Elde edilen bulgularda çocuklar için zararlı içerikle mücadele konusunda dünya genelinde ortak irade oluştuğu, ancak Türkiye'de daha kapsamlı mücadelenin saydam olmayan yöntemlerle yürütülmesinden dolayı "sansür uygulaması" algısının oluştuğu görülmektedir. Erişime kapatılan sitelere Türkiye'den erişim istatistikleri 5651 Sayılı Kanun ve uygulanan yöntemin amaçlanan hedefe ulaşmada yetersiz kaldığını göstermektedir.
\end{abstract}

Anahtar sözcükler: Internet, Sansür, Filtreleme, Erişimin engellenmesi, 5651 Sayılı Kanun, Idari Tedbir, Türkiye

\begin{abstract}
In Turkey, the fact that there are some restrictions on Internet access and that the people's perceptions of censorship may vary shows itself clearly in the literature related these issues. When review the literature; it is seen that there are many studies which demand unlimited Internet access, criticize the Law No. 5651 and argue in favor of its removal, and describe all Internet filters
\end{abstract}

* Adli Bilişim Uzmanı, Hacettepe Üniversitesi. (henkoglu@hacettepe.edu.tr)

** Prof. Dr., Hacettepe Üniversitesi Bilgi ve Belge Yönetimi Bölümü. (byilmaz@hacettepe.edu.tr) 


\begin{abstract}
and restrictions as censorship. In this study; it is aimed to evaluate the current practices in Turkey, which restrict the freedom of Internet access, in the light of existing legal regulations. In contrast to previous studies, in this one; the relationships among practices, legislations and decisions taken were examined in detail, it is questioned that to which degree the closure of web sites containing harmful content has been successful, and some suggestions were made related to what should be done in order to achieve the goal of Internet restrictions. In addition, attention was drawn on how to easily gain access to the closed web sites through alternative methods, and this situation was evaluated in respect of legal regulations regarding the freedom of information access. Furthermore, the validity of criticisms found in literature was re-evaluated through examining the legal regulations, decisions taken to prevent access, decisions of Supreme Court, and the level of intended goal state reached as a result of current implementations. The results of the study show that there is a common will around the world to fight against the harmful content targeting children; however, in Turkey due to the non-transparent methods, implementations of more comprehensive methods of struggle are perceived as censorship. In addition, the statistics regarding the closed web sites in Turkey show that the Law No. 5651 and its implementations are insufficient in terms of intended goals.
\end{abstract}

Keywords: Internet, Censorship, Filtering, Denial of access, Law 5651, Administrative measurement, Turkey

\title{
Giriş
}

İnternet, bilgi transferi ve dijital yayıncılık için önemli bir iletişim altyapısıdır. Ancak, zaman ve maliyet konusunda tasarruf sağlamaya yardımcı olan internet, başta çocuklara yönelik olmak üzere birçok tehdidi de barındırmaktadır. 1990'ı yıllardan günümüze kadar olan süreçte hızla artan yasal olmayan içerik ve özellikle çocukların araç olarak kullanılması ile ilgili kaygılar, devlet kurum ve kuruluşlarını bu konuda önlemler almaya zorlamaktadır (Akdeniz, 2001). Bilgi iletişim teknolojileri ve internetin sunduğu bilgi transferi, eriş̧im ve paylaşım kolaylığının kötü amaçla kullanımına engel olabilmek için ulusal ve uluslararası ölçekte çeşitli önlemler alınmaktadır. İnternet ortamında çocukların zararlı içerikten (yıkıcı-bölücü, kumar, uyuşturucu, dini, politik vb.) ve kötü niyetli kişilerden korunması, yasal olmayan paylaşımların engellenmesi ve istenmeyen e-posta miktarının azaltılması konularında kaygılar bulunmaktadır. Bu kaygılar, internet kullanıcılarını kendi olanakları ile önlemler almaya ya da devletlerin merkezi olarak filtreleme yöntemlerine başvurmasına neden olmaktadır. 2008 yılında yayınlanan "Çocuklara Karşı Şiddet" içerikli Birleşmiş Milletler (BM) Genel Kurulu Deklarasyonu'nda çocuk pornografisi ve diğer şiddet unsurlarına karşı önlem alma çağrısında bulunulmaktadır (BM, 2008). Bu tür tehdit ve suçları içeren yayınlara karşı mücadele edebilmek için teknik önlemlerin yanı sıra uygulanabilir nitelikte hukuki düzenlemelerin de bulunması büyük önem taşımaktadır.

1990'lı yılların ortalarından itibaren, özellikle komünizm ile yönetilen ülkelerde katı bir internet denetim ağı oluşturulmuştur. Çin'de 2008 yılı itibariyle 290 milyon çevrimiçi kullanıcının düzenli olarak internet erişiminin engellendiği bilinmektedir (Treble, 2008). İran, Özbekistan, Türkmenistan, Suriye ve Vietnam’ın da politik konularda 
internet erişimi engellemede Çin ile benzer durumda olduğu görülmektedir (Blight, Rininsland, Rogers ve Torpey, 2012). Ülkelerin sosyal ve kültürel yapısına bağlı olarak internet üzerindeki içeriğe yönelik bakış açısı farklılık gösterebilmektedir. Çin, İran ve Arap ülkelerinde siyasi içerik ve karşıt görüşlere yönelik çok katı bir sansür ve filtreleme uygulaması mevcut iken; Avrupa'da çocuk pornografisi ve ırkçılık üzerine katı bir tutum bulunmaktadır (Al-Saqaf, 2010). ABD'de de benzer şekilde, çocukları internet ortamında bulunan zararlı içerikten koruma amacı ile "Çocukların İnternetten Korunması Kanunu" (Children's Internet Protection Act - CIPA) 2000 yılında düzenlenmiş ve yürürlüğe girmiştir (CIPA, 2000). Ayrıca her eyalet, özellikle okul ve bilgi merkezlerinde kullanılan bilgisayarlar için alınacak önlemleri ve uygulanacak yöntemleri yasal düzenlemelere bağlı olarak belirlemiştir (Stone, 2012).

Zararlı içerikle mücadelenin ancak uluslararası işbirliği ile mümkün olabileceği bilincinin oluşması Avrupa Birliği'ni de harekete geçirmiş ve bir eylem planı oluşturulmuştur. 25 Ocak 1999 tarihli Avrupa Konseyi ve 276/1999/EC sayılı Avrupa Parlamentosu kararında; güvenli internet kullanımı, yasal olmayan içerikle mücadele, filtreleme araçlarının geliştirilmesi ve farkındalığın artırılmasının amaçlandığı belirtilmektedir (European Parliament, 1999). Avrupa dışından ülkelerin de katılımına açık tutulan kararda, çocuk pornografisi ve ırkçılık konularına önem verildiği görülmektedir. Kararda, filtreleme konusunda ebeveynlerin ve öğretmenlerin de etkin rol oynamaları öngörülmüştür. 276/1999/EC sayılı karar üzerinde; Türkiye'nin de katılımının sağlandığı 1151/2003/EC (European Parliament, 2003) ve 854/2005/ EC (European Parliament, 2005) sayılı kararlarla güncellemeler yapılarak eylem planı genişletilmiştir. Çocuklar için daha güvenli internet sağlamak amacıyla strateji planları çerçevesinde geliştirilen 2011/92/EU sayılı direktif (European Parliament, 2011) ve son olarak 2012/C 393/04 sayılı karar (European Council, 2012) Avrupa Birliği (AB)'nin bu konuya bakışını açık olarak ortaya koymaktadır. 2000'li yılların başından itibaren, toplum ihtiyaçlarının yanı sıra Türkiye'nin AB'ye katılma ve uyumluluğu arttırma amacıyla da yasal düzenlemelerini gözden geçirdiği görülmektedir. AB'de 1999 yılından itibaren güvenli internet kullanımına yönelik olarak alınan kararların, Türkiye'nin bu alanda yapmakta olduğu yasal düzenlemeler üzerinde etkisi bulunmaktadır (OpenNet, 2010).

Sınırsız bir internet erişim özgürlüğünün olmadığı ve dünyanın her bölgesinde belirli ölçülerde internet erişim engellemelerinin bulunduğu söylenebilir. Türkiye de kendine özgü bir içerik kontrol ve erişim engelleme politikası yürütmektedir. Ancak erişim engelleme ve filtreleme kararları zaman zaman sansür uygulamasına dönüşebilmekte ya da bu algılanın oluşmasına neden olabilmektedir. Bu algının ortadan kaldırılabilmesi için mevcut düzenleme ve uygulamalara yönelik eleştirilerin dikkate alınarak, erişim yasaklarının amacına ulaşma durumu irdelenmeli ve zararlı içerikten daha etkin korunma yöntemlerinin geliştirilebilmesi için hukuki sorumlulukların daha açık hale getirilmesi sağlanmalıdır. 


\section{Temel Kavramlar ve Türkiye'de İnternet Erişim Engellemeleri}

\section{Sansür, Filtreleme ve Erişim Engelleme}

Latin kökenli "censere" kelimesinden gelen sansür; değerlendirmek, görüş bildirmek anlamını taşımaktadır (Oxford, 1968). Günümüzde sansürün sözlük anlamı, "her türlü yayının, sinema ve tiyatro eserinin yayınının ve gösterilmesinin izne bağlı olması, sıkı denetim" şeklinde tanımlanmaktadır (Türk Dil Kurumu, 2006). İnternet öncesinde düşünce, ifade ve iletişim özgürlügü ile birlikte gündemde yer alan sansür uygulamaları internetin yaygınlaşması ile birlikte, internet erişim hakkı ve bilgi edinme hakkı konularıyla da yoğun olarak tartışılmaktadır. İkinci Dünya Savaşı yıllarından itibaren müstehcenlik', politika, sosyal ve din alanlarında bilgi merkezlerinde yoğun olarak uygulanan sansürün günümüzde bilgi kaynaklarının daha fazla bulunduğu internet üzerinde uygulandığı görülmektedir (Oppenheim ve Smith, 2004). Ancak internet sansürü ülke, kültür ve içeriğe (çocuk pornografisi, terörizm, kumar vb.) bağlı olarak değişen yeni ve önemli bir olgudur (Al-Saqaf, 2010). İnternete ilişkin "filtreleme" deyimi ise, bir otorite tarafından uygulandığında sansür ile aynı anlamı taşımakta ve çoğu zaman sansür uygulamasının teknik ifadesi olarak kullanılmaktadır. Toplum ahlâkının korunması, çocukların korunması ve güvenlik gibi gerekçelerle birçok ülkede çocuk istismarı, şiddet, ırkçılık, uyuşturucu, kumar, terörizm ve pornografik içeriğe filtre uygulanmaktadır (Bothma, 2010). Demokratik toplumlarda filtreleme sorumluluğu, kullanııının kendi iradesi ile yapacağı tercihlere bırakılmaktadır.

Tartışmaların özünü, internet sansürünün varlığının kabullenilmesi ve hangi durumda erişim engellemesinin uygulanacağı konusu oluşturmaktadır. Müstehcenliğin ve pornografik içeriğin neler olduğunun tanımlanamadığı noktada, internet sansürün tanımının yapılabilmesi güçtür (Jones, 1999). Malley'e (Malley, 1990, s.21) göre sansürün hangi ölçüde uygulanacağı, politik düşünceye bağlı olarak değişmektedir. Bu noktada aynı otorite tarafından uygulanan ve özgürlüğü kısıtlayan sansür ile erişim engelleme arasındaki farkın da dikkate alınması önemlidir. Engelleme, toplum içerisinde etik olarak yayılması istenmeyen bir etkinliğin durdurulması için konulmuş kesin ve açık kurallardır. Sansür ise, bireylerin ya da toplumun düşünce ve ifadesini baskı altına alan bir yaklaşımdır. Bu yönü ile sansür, otoritenin kaygılarını gidermede kullanılan daha katı bir tutumun yansımasıdır (Prabhat, 2011). Sansür ile erişim engelleme arasındaki anlamsal ve uygulamadaki farklılık erişim engellemelerini meşru hale getirmektedir. Bu nedenle, otoriteler sansür uygulamalarını da "erişim engelleme" ifadesiyle ve yasal düzenlemelere dayandırarak hayata geçirmektedirler.

\section{Türkiye'de İnternet Erişim Engellemelerine Illişkin Tarihsel Süreç}

İnternet ile 1993 yılında tanışan Türkiye'de, internetin kullanımı 1990'lı yılların sonundan itibaren yaygınlaşmaya başlamıştır. 2000'li yılların başına kadar olan dönemde, Türkiye'de internet kullanımına yönelik doğrudan ve genel müdahale olmamıştır.

1 Müstehcen: Açık saçık, edebe aykırı, yakışıksız (Türk Dil Kurumu, 2013) 
Türkiye'nin internet ile tanıştığı tarihten itibaren erişim engellemeleri ile ilgili gelişmeler dikkate alındığında, internet erişim engellemeleri ve içeriğe müdahalenin üç döneme ayrılarak açıklanabileceği görülmektedir. Bunlar; 1993-2000 yılları arasındaki internet ile tanışma ve kullanımın yaygınlaşması dönemi, 2001-2006 yılları arasındaki hukuki düzenlemeler ile müdahale dönemi ve 2007 ve sonrası 5651 Sayılı Kanun çerçevesinde başlayan erişim engelleme dönemidir.

1993-2000 yılları arasında eski Türk Ceza Kanunu'nun 159. Maddesinde² yer alan ifade suçları ile ilgili düzenleme, bu alandaki sorunları çözmek için yeterli görülmüştür. İnternet sansürü olarak değerlendirilebilecek ilk müdahale 2001 yılında 4676 sayılı "Radyo ve Televizyonların Kuruluş ve Yayınları Hakkında Kanun, Basın Kanunu, Gelir Vergisi Kanunu ile Kurumlar Vergisi Kanununda Değişiklik Yapılmasına Dair Kanun Tasarısı" (T.C. Başbakanlık, 2001) ile yapılmıştır. Tasarının içinde yer alan, 5680 Sayılı Basın Kanunu'nu değiştiren Ek Madde-9'daki ifadeyle ${ }^{3}$; internet yayıncılığı, basın yayın organları ve yazılı-basılı bilgi kaynakları aynı değerlendirme sınıfına alınmaya çalışılmıştır. 5680 sayılı Basın Kanunu'nda (5680 Sayılı Kanun, 1950) basılı yayınlar için belirtilen koşulların internet üzerinde de sağlanmasının yeni sorunlara neden olabileceği öngörüldüğü için bu tasarı 18 Haziran 2001 tarihinde Cumhurbaşkanı tarafından veto edilmiş ve yürürlüğe girmemiştir. Veto gerekçeleri arasında; kişilik haklarının korunması, düşünce ve ifade özgürlüğü gibi konuların internet yayıncılığında kamu otoritelerinin takdirine bırakıldığının ve internet yayıncılığına ilişkin ilkelerin özel bir kanun ile yapılmasının en doğru yol olacağının belirtilmesi, tasarının kanunlaşması halinde internet üzerinde düşünce ve ifade özgürlüğüne nasıl gölge düşüreceğini açıklamaktadır (T.C. Cumhurbaşkanlığı, 2001). Türkiye'de internet sansürünün tarihi, bu önemli müdahale ile birlikte 2001 yılında başlamıştır. 15 Mayıs 2002 tarihinde tekrar Türkiye Büyük Millet Meclisi (TBMM) gündemine alınan ve aynen kabul edilen 4676 Sayılı Kanun, anayasa gereği ${ }^{4}$ kabul edilerek 4756 Sayılı Kanun ismiyle içeriği değişmeden yürürlüğe girmiştir (4756 Sayılı Kanun, 2002). Böylece 4756 Sayılı Kanunun yalan haber, hakaret ve benzeri fiillerden doğacak maddî ve manevî zararlarla ilgili hükümlerinin; internet ortamında yer alan içerik hakkında da uygulanmasının yolu açılmıştır. 5680 Sayılı Basın Kanunu'nun yerini alarak 2004 yılında yürürlüğe giren 5187 Sayılı Basın Kanunu'nda (5187 Sayılı Kanun, 2004) ise internet yayıncılığına yer verilmemiş ve bu konu kanun kapsamı dışına çıkarılmıştır.

2765 Sayılı Türk Ceza Kanunu. 159. Madde: "Türklüğü, Cumhuriyeti, Büyük Millet Meclisini, Hükümetin manevi şahsiyetini, Bakanlıkları, Devletin askeri veya emniyet muhafaza kuvvetlerini veya Adliyenin manevi şahsiyetini alenen tahkir ve tezyif edenler altı aydan üç seneye kadar hapis cezası ile cezalandırıırlar."

34676 Sayılı Kanun Tasarısı, Ek Madde-9: "Bu Kanunun yalan haber, hakaret ve benzeri fiillerden doğacak maddî ve manevî zararlarla ilgili hükümleri, bilişim teknolojileri ve internet ortamında sayfa açılması veya elektronik gazete, elektronik bülten vb. suretiyle yayınlanan her türlü yazı, resim, işaret, sesli veya sessiz görüntü ve benzerleri hakkında da uygulanır."

4 T.C. Anayasası, 89.Madde, 3.Fıkra: "Türkiye Büyük Millet Meclisi, geri gönderilen kanunu aynen kabul ederse, kanun Cumhurbaşkanınca yayımlanır; ..." 
İnternet kullanımının ve buna bağlı olarak bilişim suçlarının hızla arttığı 2001-2006 yılları arasında Türk Ceza Kanunu, Fikir ve Sanat Eserleri Kanunu ve Medeni Kanun'da yer alan düzenlemelere dayanarak birçok site için kapatma kararı alınmıştır. Bu dönemde içeriğin yurt dışından yayınlanıyor olması gibi nedenlerden dolayı, zararlı içeriğin bulunduğu internet sayfalarına erişimin engellenmesi yerine sitenin tamamına erişim kısıtlanmasının uygulanması yöntemine başvurulmuştur. Bu nedenle, 2001-2006 yılları arasında aşırı olarak nitelendirilebilecek erişim kısıtlamaları yapılmıştır.

5651 Sayılı Kanun ile birlikte başlayan yeni dönemde sansür uygulamaları açısından Türkiye'nin notunun düşük olduğu görülmektedir. Mevcut istatistiksel veriler, Türkiye'nin kültürel değerlere bağlı olarak yapmış olduğu erişim engellemelerinin de uluslararası çevrelerde açıklanmasını zorlaştırmaktadır. ABD İnsan Hakları Raporu'da dâhil olmak üzere birçok akademik çalışmada kaynak gösterilen engelliweb.com isimli internet sitesinde site ziyaretçilerinin katkıları ile oluşturulan erişime engelli web sitelerinin listesine ulaşmak mümkündür. Engelliweb.com adresinde yer alan başlıca istatistiksel veriler Şekil 1'de gösterilmektedir.

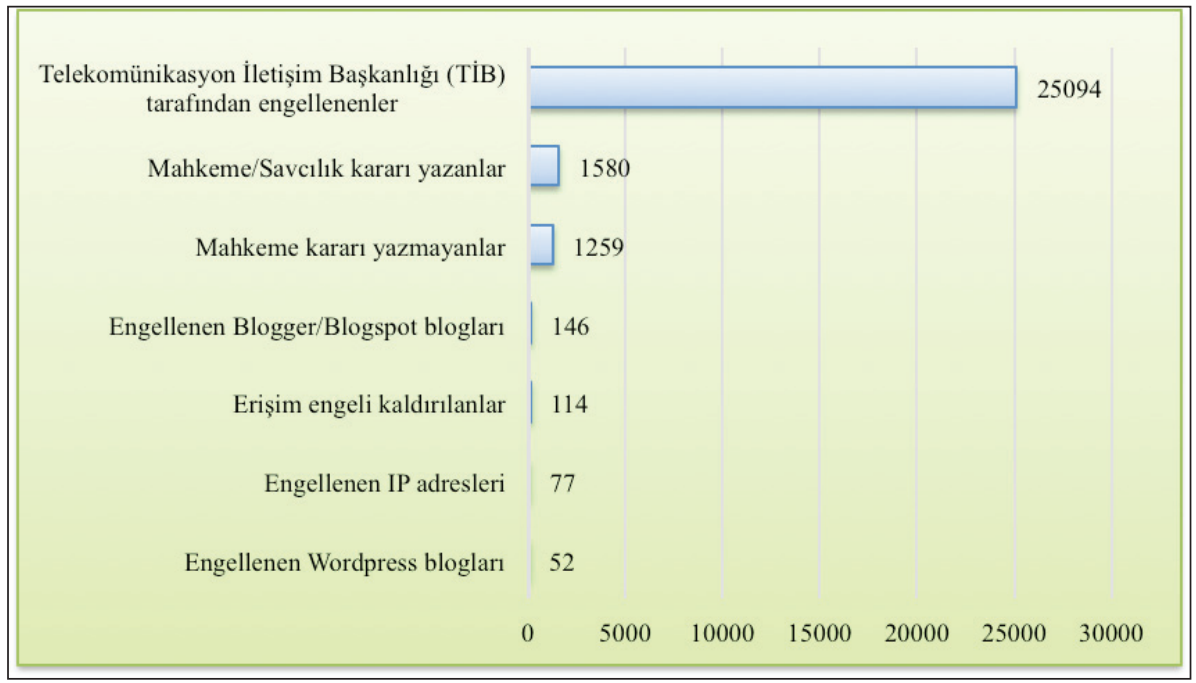

Şekil 1. Erişime Engellenen İnternet Sitelerine Ait İstatistikler (Engelliweb, 2013)

2008 yılından itibaren isimleri tespit edilen ve listelenen erişime kapatılmış web sitesi sayısı 10 Nisan 2013 tarihi itibariyle 29.006 olduğu, ancak gerçek sayının 30.000'in üzerinde olduğu tahmin edilmektedir. Mahkeme ve savcılığın kapatma kararlarının da içinde yer aldığı 29.006 internet sitesinin \%86,8'inin TiB kararı ile erişime engellenmiş olması dikkat çekicidir. Mahkeme kararı ya da onay alma şartı olmaksızın internet içeriğinin servis sağlayıcılar üzerinden erişime kapatılması, uluslararası raporlarda 
olumsuz gelişmeler arasında değerlendirilmektedir. Devletin resmi kurumlarından, erişime engellenen web sitesi sayısı ile ilgili yapılmış herhangi bir güncel açıklama bulunmamaktadır (OSCE, 2010). Türkiye'de internet bağlantısı; ticari internet bağlantı altyapısı ve üniversiteler ile devlet kuruluşlarına hizmet veren ULAKNET eğitim ağı altyapısı üzerinden sağlanmaktadır. İnternet trafiği üzerindeki filtreleme işlemlerinin büyük bölümü Türk Telekom ticari altyapısı üzerinde yapılmaktadır (Bitso, Fourie ve Bothma, 2012).

\section{Erişim Engellemelerine İlişkin Hukuk Mevzuatı ve Uygulamanın Değerlendirilmesi}

Bir internet sitesinin erişime kapatılması, genellikle üç farklı gerekçeye bağlı olarak uygulanmaktadır. Bunlar; Türk Medeni Kanunu'nun 24. ve 25 . Maddelerinde ${ }^{5}$ belirtilen kişilik haklarının ihlali ile ilgili gerekçeler, Fikir ve Sanat Eserleri Kanunu'nun 4. Ek Maddesinde ${ }^{6}$ belirtilen telif hakları ihlali ile ilgili gerekçeler ve 5651 Sayılı Kanunun 8. Maddesinde yer alan katalog suçlardır. Türk Medeni Kanunu ve Fikir ve Sanat Eserleri Kanunu kapsamındaki suçlar, takibi şikâyete bağlı olan suçlar arasında yer almaktadır. Bu nedenle hak sahibinin internet üzerinde bulunan yasadışı içerikle ilgili olarak içeriği yayınlayan siteye ihtarda bulunması ve içeriğin yayından kaldırılmaması halinde savcılığa suç duyurusunda bulunması gerekmektedir. Bu tür suçlarla TíB değil, mahkemeler ilgilenmektedir. Erişim engellemeleri ve sansür uygulamaları kapsamında, ağırlıklı olarak TiB tarafından 5651 Sayılı Kanun çerçevesinde uygulanan idari tedbir kararları tartışılmaktadır.

\section{Sayılı Kanun ve Idari Tedbir Olarak Engelleme Kararının Alınması}

İnternet ortamında işlenen suçların yaygınlaşması ile birlikte dünya genelinde olduğu gibi Türkiye'de de içerik denetimi ile ilgili önlemlerin alınması zorunlu hale gelmiştir. İnternet ortamında içerik denetiminin yapılmasına yönelik olarak yapılan ilk kapsamlı hukuksal düzenleme 2007 yılında yürürlüğe giren 5651 Sayılı Kanun'dur. 5651 Sayılı Kanun; çocukları, gençleri ve aileyi kötü alışkanlıklara teşvik eden, fiziksel, zihinsel ve ahlaki gelişimi zedeleyen yayınların içeriklerinden korumak için önleyici tedbir almak amacıyla düzenlenmiştir. Kanun'un içeriğinde; elektronik ortamda işlenen belirli suçların içerik, yer ve erişim sağlayıcılar üzerinden önlenmesine ilişkin usul ve esaslar yer almaktadır. Bu nedenle içerik sağlayıcı, yer sağlayıcı ve erişim sağlayıcının tanımı ve yükümlülükleri Kanun'da belirlenmiştir. İnternet üzerinde yer alan yayınların hangi nitelikleri taşıması gerektiği ise "Internet Ortamında Yapılan Yayınların Düzenlenmesine Dair Usul ve Esaslar Hakkında Yönetmeliğin" 4. maddesinin birinci

5 Türk Medeni Kanunu Madde 24.- Hukuka aykırı olarak kişilik hakkına saldırılan kimse, hâkimden, saldırıda bulunanlara karşı korunmasını isteyebilir. Madde 25.- Davacı, hâkimden saldırı tehlikesinin önlenmesini, sürmekte olan saldırıya son verilmesini, sona ermiş olsa bile etkileri devam eden saldırının hukuka aykırılığının tespitini isteyebilir.

6 FSEK Ek Madde 4 - “... İhlâlin devamı halinde bu defa, Cumhuriyet savcısına yapılan başvuru üzerine, üç gün içinde servis sağlayıcıdan ihlâle devam eden bilgi içerik sağlayııısına verilen hizmetin durdurulması istenir." 
fıkrasında açıklanmıştır (T.C. Başbakanlık, 2007). Bu yönetmelikte ağırlıklı olarak içerik sağlayıcılarının yükümlülükleri yer almaktadır.

"Internet Kanunu" olarak da adlandırılan 5651 sayılı Kanun, internet ortamında yer alan yayınlara erişimle ilgili özel nitelikli bir kanundur. Erişimin engellenmesine neden olabilecek suçların bu özel yasada düzenlenmiş olması nedeniyle bir internet sitesine erişimi engelleme kararı alınabilmesi için, hukukun genel kuralı gereği 5651 Sayılı Kanun'a başvurulması zorunludur (Hukuk Bilgi Bankası, 2012). 5651 Sayılı Kanunun en önemli işlevi, tanımlanmış olan katalog suçlarla mücadele için gerekli tedbirlerin alınmasını sağlamaktır. Diğer kanunların da bu alan kapsamındaki konularla ilgili olarak 5651 sayılı kanuna göre değerlendirilmesi gerekmektedir. Nitekim 2011 yılında kabul edilen "Radyo ve Televizyonların Kuruluş ve Yayın Hizmetleri Hakkında Kanun"un 44. maddesinin 7. fıkrasında7; internet içeriği ile ilgili sorunların çözümünde 5651 sayılı Kanun hükümlerine başvurulabileceği belirtilmektedir (6112 Sayılı Kanun, 2011). Bu nedenle, 5651 Sayılı Kanunun sansür uygulamasına dönüşmeksizin uygulanabilirliğinin sağlanması önem taşımaktadır. Uygulamadaki belirsizlikler, hukuka uygun olmama durumunun gerçekleşmesi ve aynı zamanda internet sansürünün oluşması anlamına gelebilmektedir.

İdari tedbir olarak uygulanan erişim kısıtlamaları Türkiye'de TiB tarafından uygulanmaktadır. TiB İnternet Dairesi, görev ve yetkilerini; «İnternet Ortamında Yapılan Yayınların Düzenlenmesi ve Bu Yayınlar Yoluyla İşlenen Suçlarla Mücadele Edilmesi Hakkında Kanun», "Telekomünikasyon Kurumu (Bilgi Teknolojileri ve İletişim Kurumu) Tarafından Erişim Sağlayıcılara ve Yer Sağlayıcılara Faaliyet Belgesi Verilmesine İlişkin Usul ve Esaslar Hakkında Yönetmelik", "Internet Toplu Kullanım Sağlayıcıları Hakkında Yönetmelik", "Internet Ortamında Yapılan Yayınların Düzenlenmesine Dair Usul ve Esaslar Hakkında Yönetmelik" ve "Bilgi Teknolojileri ve Illetişim Kurumu Tarafından Erişim Sağlayıcılara ve Yer Sağlayıcılara Faaliyet Belgesi Verilmesine İlişkin Usul ve Esaslar Hakkında Yönetmelikte Değişiklik Yapılmasına Dair Yönetmelik" çerçevesinde icra etmektedir (TiB, 2012).

5651 Sayılı Kanun ve ona bağlı olarak çıkarılan “Internet Ortamında Yapılan Yayınların Düzenlenmesine Dair Usul ve Esaslar Hakkında Yönetmelik", internet üzerinden hosting ${ }^{8}$ hizmeti sunan firmalara ve servis sağlayıcılara belirli kısıtlamalar getirme ve erişimi engelleme hakkını Tỉ'e vermektedir. Ancak erişime engellenecek sitelerle ilgili suçlar katalog halinde tanımlandığı için, sadece bu suçların erişimi engellenebilmektedir. 5651 Sayılı Kanunun 8. Maddesinin 1. Fıkrasında, erişimin engellenmesine konu olabilecek suçlar yer almaktadır (5651 Sayılı Kanun, 2007). Bu suçlar;

76112 Sayılı Kanun. 44.Madde, 7.Fıkra: “Bu Kanunun uygulanması açısından, 4/5/2007 tarihli ve 5651 sayılı İnternet Ortamında Yapılan Yayınların Düzenlenmesi ve Bu Yayınlar Yoluyla İşlenen Suçlarla Mücadele Edilmesi Hakkında Kanun hükümleri saklıdır."

8 Hosting: Bir web sayfası içeriğinin sunumcu bilgisayar üzerinde bulundurulması ve internet üzerinde yayınlaması (erişilebilir hale getirilmesi) işlemidir. 
$\diamond \quad$ 26/9/2004 tarihli ve 5237 sayılı Türk Ceza Kanunu'nda (TCK) yer alan;

- İntihara yönlendirme (madde 84),

- Çocukların cinsel istismarı (madde 103, birinci fıkra),

- Uyuşturucu veya uyarıcı madde kullanılmasını kolaylaştırma (madde 190),

- Sağlık için tehlikeli madde temini (madde 194),

- Müstehcenlik (madde 226),

- Fuhuş (madde 227),

- Kumar oynanması için yer ve imkân sağlama (madde 228),

$\diamond \quad$ 25/7/1951 tarihli ve 5816 sayılı “Atatürk Aleyhine İşlenen Suçlar Hakkında Kanun”da yer alan suçlardır.

5651 Sayılı Kanun'un 10. Maddesinin 5. Fıkrasında ise Tỉ'e kanun maddesinde belirtilen bakanlıkların katılımıyla oluşturulacak internet kurulu ile işbirliği ve koordinasyonu sağlama görevi verilmiştir. Bu kurul, filtreleme ve engelleme yapılacak yayınların tespiti ile gerekli önlem ve kararların alınması konusunda yetkili kılınmıştır. Filtreleme ve engelleme yapılacak içeriğin belirlenmesinde; İnternet Ortamında Yapılan Yayınların Düzenlenmesine Dair Usul ve Esaslar Hakkında Yönetmeliğin "ilkeler" başlıklı 4. Maddesinin 1. Fıkrasında yer alan esaslar dikkate alınmaktadır (26716 Sayılı Yönetmelik, 2007). Yayın içeriğine ilişkin 1. Fıkrada yer alan esaslar ise şunlardır:

$\diamond$ Insan onuruna, temel hak ve hürriyetlere saygılı olmalıdır.

$\diamond$ Gençlerin ve çocukların fiziksel, zihinsel ve ahlaki gelişimini zedeleyecek türden içeriklere yer vermemelidir.

$\diamond \quad$ Ailenin huzur ve refahını sağlayan hususlara zarar verecek nitelikte olmamalıdır.

$\diamond$ Kişileri, uyuşturucu madde bağımlılığı, fuhuş, müstehcenlik ve kumar gibi kötü alışkanlıklara teşvik edici olmamalıdır.

5651 Sayılı Kanun kapsamında zararlı içeriğe sahip bir internet sitesi erişime engellenmeden önce, internet sitesinin bulunduğu sunucunun yurt içinde mi ya da yurt dışında mı olduğuna bakılmaktadır. Yurt içinde hizmet veren bir sunucu üzerindeki zararlı içeriğin yayından kaldırılması ya da sitenin erişime engellenmesi soruşturma sırasında hâkim, kovuşturma sırasında ise mahkeme kararı ile yapılmaktadır. Gecikmesi sakıncalı olan hallerde, 24 saat içinde hâkim onayına sunulmak şartıyla Cumhuriyet savcısı tarafından da karar verilebilmektedir. Ayrıca, çocukların cinsel istismarı ve müstehcenlik ile ilgili suçlarda da hâkim onayına sunmak şartıyla TiB tarafından erişimin engellenmesi kararı verilebilmektedir. İçerik ya da yer sağlayıcının yurt dışında olması durumunda ise erişim engelleme kararı doğrudan TiB tarafından alınmakta ve erişim sağlayıcı tarafından kararın gereği yerine getirilmektedir. Tỉ tarafından alınan ve uygulanan bu karar kalıcı niteliktedir ve sonradan hâkim onayına sunulmamaktadır. İçeriği yayınlayanların kimliğinin belirlenmesi halinde, TỉB tarafından ayrıca suç duyurusunda bulunulmaktadır 
(5651 Sayılı Kanun, 2007). Bu konuda ihtisaslaşmış mahkemelerin bulunmaması ve mahkemelerde bilirkişi görüşüne başvurulmaması, eleştirilerin odağında yer almaktadır. Ayrıca, özellikle yurt dışındaki erişime kapatılan sitelerle ilgili olarak bilgilendirme ve savunmanın alınması işlemlerine uygulamada yer verilmediği görülmektedir.

\section{Güvenli Internet Erişimine Ilişkin Usul ve Esaslar}

5651 Sayılı Kanun'un uygulanmasına paralel olarak Bilgi Teknolojileri ve İletişim Kurumu (BTK) tarafından 2011 yılında "Güvenli İnternet Hizmeti" başlatılmıştır (BTK, 2012). Anayasa'nın 41. ve 58. maddeleri gereğince çocukların, gençlerin ve ailelerin korunmasını amaçlayan bu hizmetin kullanılması konusunda kullanıcılara seçme özgürlüğü tanınmaktadır. Kullanıcılar tercih etmiş oldukları profile dâhil edilmektedirler. Profilin içeriği ise, Güvenli İnternet Hizmetine Dair Usul ve Esaslarıın 10. maddesinde tanımlanan "Çocuk ve Aile Profil Kriteri Çalışma Kurulu" tarafından belirlenmektedir (BTK, 2011). Güvenli internet hizmetiyle tanımlanan profile bağlı olarak filtreleme yapılmaktadır.

Güvenli internet hizmeti, demokratik bir çözüm olarak kullanıcıların özgürlüğünü desteklemektedir. Ancak kullanıcıların erişimi engellenecek siteler üzerinde kendilerinin de belirleyici olmaları ve 5651 Sayılı Kanun içerisinde bu özgürlüğün sunulması ile daha fazla benimsenen, işlevsel bir uygulamaya dönüşeceği değerlendirilmektedir. Aile ve çocuk filtrelerinde yer alan ya da çıkarılan internet sitelerinin ölçütleri hakkında açık bir bilgi bulunmamaktadır. Her ne kadar bir profil seçme ya da seçmeme özgürlüğünün sunulması ile demokratik bir yaklaşım olsa da içeriğin devlet tarafından belirlenmesi ve saydam olmayan bir internet çerçevesinin oluşturulması, bu projedeki demokrasi anlayışını tartışmalı hale getirmektedir.

\section{İnternet Erişim Engellemelerinin Etkileri ve Sonuçları}

\section{Erişim Engelleme Politikası ve Engellenen Sitelere Erişim için Kullanılan Yöntemler}

İnternet üzerindeki bilgi kaynaklarına erişimin engellenmesi amacıyla kullanılan birçok yöntem bulunmaktadır (Al-Saqaf, 2010). Ancak Türkiye'de yaygın olarak kullanılan yöntemler alan adı sunucuları ${ }^{9}$ (Domain Name Server - DNS) üzerinden ilgili alan adına erişimin engellenmesi ve yönlendiricilerin erişim listeleri kullanılarak IP (internet protokol) adresi üzerinden erişimin engellenmesidir. IP adresi engelleme yöntemi erişilmek istenen web sitesinin IP adresi ve port numarasının kara listede yer alan IP adresleri ve port numaraları ile karşılaştırılması esasına dayanmaktadır. Bir IP adresine tanımlanmış birden fazla alan adına ait içeriğin bulunması halinde alan adına erişimin kapatılması yöntemi uygulanmaktadır. Alan adı sunucuları üzerinde IP ve alan adı

9 Alan adı sunucuları (DNS): Erişilmek istenen ve web tarayıcıda yazılan internet sitesinin IP adresini elde etmek amacıyla kullanılmaktadır. 
eşleştirme bilgisinin hatalı olması sağlanarak, erişilmek istenen internet sayfasına engel olunabilmektedir. İnternet erişim kapatma kararının belirtildiği bilgilendirme sayfasına yapılan yönlendirme işleminde de bu yöntem kullanılmaktadır.

İnternet ortamındaki zararlı içeriğe erişimi engellemek için devletlerin uyguladığı yöntemler, içeriğin yayından kaldırılması ya da erişim sağlayıcılar üzerinden filtreleme ile sınırlı değildir. Bunun dışında; servis sağlayıcılar ve bilgi erişiminde çok önemli bir role sahip olan arama motorları üzerinden, anahtar kelimelere bağlı filtreleme yöntemlerine de başvurulmaktadır. İnternet ortamında herhangi bir bilgiye ulaşma aracı olarak kullanılan en önemli araçlardan biri olan arama motorları üzerinden yapılan filtrelemeler, dünya genelinde en etkili erişim engelleme yöntemlerinden biri olarak tercih edilmektedir. Bilgiye ulaşmak için başvurulan bilgi kaynaklarını gösteren araştırmalarda bilgi aramaya kütüphane web sayfaları ile başlayan kullanıcıların oranı \%1'in altında olduğu halde arama motorları başlayan kullanıcıların oranının \%84 olduğu görülmektedir (OCLC, 2010). Dünya genelinde veTürkiye'de en çok ziyaret edilen internet sitelerinin ilk beş sırasında arama motorları ile başlayan ve sosyal paylaşım sitelerinin yer alması, bu alanlar üzerindeki filtrelemenin son yıllarda neden daha fazla önem kazandığını göstermektedir (Alexa, 2013a). Google tarafından yayınlanan saydamlık raporu verilerine göre, Türkiye'nin de arama motorları üzerinden bazı internet siteleri ya da içeriğe yönelik erişimin engellenmesi için taleplerinin olduğunu ve bu taleplerin 2012 yılındaki sayısında bir önceki döneme göre \%1013 artış olduğu görülmektedir. Google, TiB tarafından alınan bu taleplerin uygun görülen büyük bölümüne erişim kısıtlaması uyguladığını açıklamaktadır (Google, 2012).

IP ve DNS filtreleme yöntemleri kullanılarak yapılan erişim engellemeleriyle herhangi bir siteye erişimin kesin olarak engellenmesi mümkün değildir. DNS ayarlarının değiştirilmesi, sanal özel ağ (virtual private network - VPN) programlarının kullanılması ve farklı ülkelerden hizmet sunan proxy sunucuların üzerinden bağlantı yöntemleri kullanılarak erişime engellenen internet sitelerine girilebilmektedir. İnternet üzerinde bulunan onlarca siteden, bu bağlantıların nasıl yapılacağına ilişkin bilgiye kolaylıkla ulaşılabilmektedir. Dünya genelinde internet erişim engellemeleri ve sansür uygulamalarının her geçen gün daha yaygın hale gelmesi ile orantılı olarak bu tür engellerin aşılmasına yönelik çözüm yolları sunan kılavuzlar da internet üzerinde yaygınlaşmıştır (Howtobypassinternetcensorship.org, 2011).

Erişim engelleme yöntemi ile amaçlanan hedefe ulaşılmasının önündeki en büyük engellerden biri, katlanarak çoğalan ve bilginin transferi ile hızla yayılan içeriğin kontrol edilememesidir. Arama motorları ve web sitesi kayıt şirketlerinden elde edilen verilere dayalı ölçüm sonuçlarına göre yaklaşık 700 milyon web sitesi ve bu sitelerde 15 milyar web sayfasının olduğu tahmin edilmektedir (Singh, 2013). Netcraft tarafından düzenli aralıklarla yapılan araştırma sonuçları da bu sonuçlarla tutarlılık göstermektedir. Netcraft'ın araştırmasında internet üzerinde 649.072 .682 web sitesinden yanıt 
alınabildiği belirtilmektedir (Netcraft, 2013). Sadece ABD'de dahi her 39 dakikada yeni bir pornografik video oluşturulmakta ve internet üzerinden yayınlanmaktadır (Özkan ve Arıkan, 2009). Bu sitelerin ne kadarının erişim engellemeyi gerektiren içeriğe sahip olduğunu doğru olarak tespit edebilmek ve her gün eklenen yeni sitelerin takibini yaparak kontrolü sağlamak, her birinin ayrı ayrı kontrol edilerek karar alınması ile mümkün görünmemektedir.

\section{Engelleme Kararlarının Uygulanmasına Yönelik Eleştiriler ve Uluslararası Çerçevede Türkiye'nin Görünümü}

2007 yılında yürürlüğe giren 5651 sayılı "Internet Ortamında Yapılan Yayınların Düzenlenmesi ve Bu Yayınlar Yoluyla İşlenen Suçlarla Mücadele Edilmesi Hakkında Kanun", Türkiye'de internet sansürü konusunda en fazla tartışılan kanun olarak yerini almıştır. Mahkeme kararı olmaksızın internet sitelerine erişimin engellenebilmesi, mahkeme kararı olsa dahi içeriğin kanuna aykırı olduğunun nasıl ölçüldüğünün açık olmaması, ilgili içeriğe erişimin kısıtlanması yerine tüm siteye erişimin kısıtlanması kararının kolaylıkla verilebilmesi ve kişisel verileri koruma kanunu ile korunmayan bir kullanıcı kayıt sisteminin uygulanması, 5651 Sayılı Kanunun en fazla eleştirilen yönleridir. Kişisel verileri koruma altına almadan bireyi koruma düşüncesi, uygulamada bireylerin izlenmesine ve bilgi erişiminin engellenerek sadece devletin korunmasına olanak sağlayan bir yapıya dönüşmektedir. Bireylerin lehine olmayan bu tür denetim ve kısıtlamalar, sansür uygulamaları olarak nitelendirilmektedir.

Yasal düzenlemelere bağlı olarak TiB tarafından servis sağlayıcıların filtrelemeye ilişkin uymalarını istediği kısıtlamalar, hosting hizmetlerinde kullanılması yasaklanan sözcüklerle ilgili listenin içeriğine bağlı olarak sansür uygulamasına dönüşebilmektedir (NTVMSNBC, 2011). Erişim engellemelerine ilişkin diğer önemli konu ise alınan engelleme kararlarının büyük bölümünü oluşturan müstehcenliktir. TCK'nın 226. maddesi'nde (Türk Ceza Kanunu, 2004) ve 5651 Sayılı Kanunda katalog suçlar arasında bulunan müstehcenliğin ve çocuk pornografisinin tanımı, Türk Hukuk Mevzuatında açık olarak yer almamaktadır. Müstehcenlik konusunun kapsam ve içeriği hakkında fikir veren hukuk kaynakları olarak Yargıtay içtihatları kullanılabilir. Fakat bu konuda da TiB tarafından nasıl bir yöntem izlendiği de açık değildir. Bu nedenle hatalı uygulamaların olabileceği değerlendirilmektedir. Oysa çocuk pornografisi konusunda hassas olan AB düzenlemelerine bakıldığında, bu kavramın mevzuat içerisinde 2001 yılında açıklandığı görülmektedir (European Commission, 2001). Benzer şekilde, Birleşmiş Milletler tarafından Çocuk Hakları Sözleşmesi'ne ek olarak 2000 yılında hazırlanan ve Türkiye'nin 2004 yılında imzalamış olduğu protokolde de çocuk pornografisinin tanımı ${ }^{10}$ açık olarak yer almaktadır (CRIN, 2000).

10 Article-2/c: Çocuk pornografisi; çocuğun cinsel amaçla teşhir edilmesi ya da çocukların gerçek veya gerçek dışı olarak cinsel aktivitelerde bulunuyor gibi gösterilmesidir. 
Herhangi bir web sitesinin durumunun ve kim tarafından engellendiğinin öğrenilmesini sağlayacak bir sorgulama sayfası TiB tarafından hizmete sunulmuştur (TiB, 2013). Ancak burada erişimi engellenen sitelerin sayısı hakkında istatistiksel bilgi sunulmamaktadır. TiB tarafından erişime kapatılan web sitelerine ilişkin en son 11 Mayıs 2009 tarihinde açıklama yapılmıştır. 2009 yılında kapatılan toplam web sitesi sayısı 2601 iken, bu sitelerin \%82'sinin TiB tarafından verilen idari kararla kapatılmış olması dikkat çekicidir. 2009 yılından itibaren TỉB tarafından sadece "erişimin engellenmesi tedbirlerinin suç türlerine göre oransal dağılımı" yayınlanmaktadır. 21 Mart 2013 tarihi itibariyle TiB tarafından resen alınan kararların dağılımı Şekil 2'de görüldüğü gibidir (TiB, 2013).

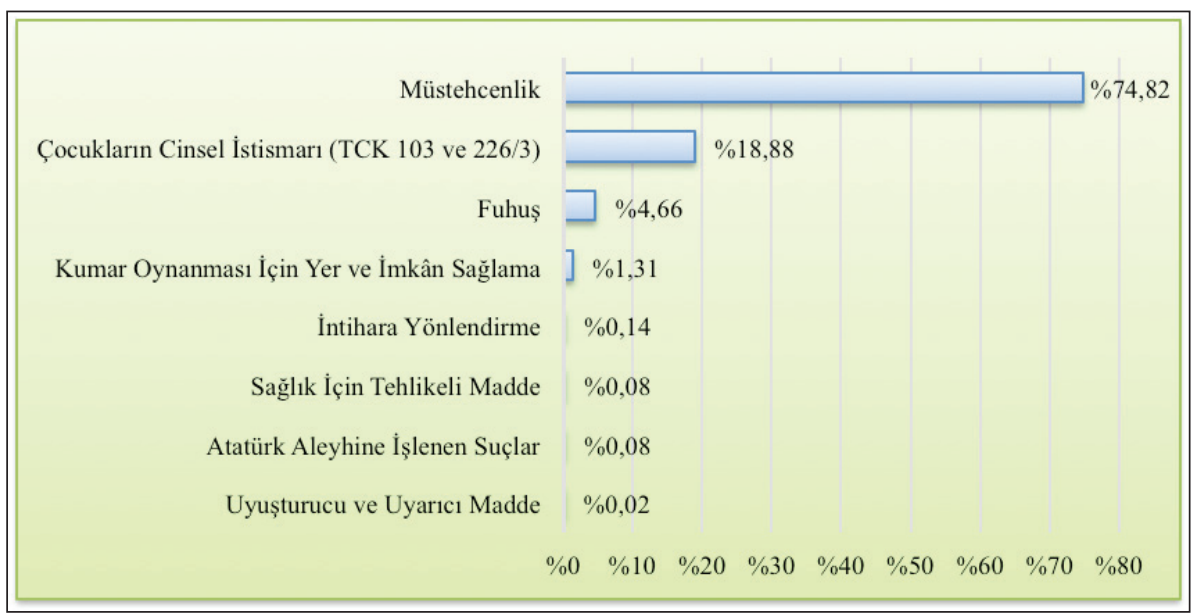

Şekil 2. Erişimin Engellenmesi Tedbiri İstatistikleri

Sansür uygulamalarına karşı küresel çapta mücadele eden "Sınır Tanımayan Gazeteciler" tarafından 2012 yılında yayınlanan raporda, Türkiye, gözetim altındaki ülkeler arasında gösterilmiştir. Raporda 2011 ve 2012 yılına ait şu ayrıntılar yer almaktadır (RWB, 2012);

$\diamond \quad$ Mahkeme kararıyla ya da TiB tarafından erişime kapatılan internet sitesi sayısı, bir önceki yıla göre iki kat artarak 15.596'e ulaşmıştır.

$\diamond 2011$ yılında BTK tarafından servis sağlayıcılara verilen ve 138 kelimeden oluşan filtreleme listesi, içerdiği kelimeler (yerli, gizli, itiraf vb.) nedeniyle anlamsız bulunmaktadır.

$\diamond$ BTK tarafından başlatılan "Güvenli İnternet Kullanımı" projesi kapsamında uygulanmakta olan isteğe bağlı merkezi filtreleme sisteminin hangi prosedüre göre yapılandırıldığı açık değildir. Yapılan testlerde uygulamanın aşırı kısıtlamalar içerdiği 
ve çevrimiçi özgürlüğü kısıtladığı görülmüştür. Hangi kısıtlamaların yapılacağına devlet değil, aileler karar vermelidir. Aralık 2011 itibariyle 11,5 milyon internet kullanıcısından sadece $\% 0,19$ 'u bu sistemi kullanmaktadır.

Avrupa'da sayısal yayıncılığa geçişte dijital sivil hakların savunuculuğunu yapan ve 21 farklı ülkeden 35 derneğin oluşturduğu "Avrupa Sayısal Hakları" (European Digital Rights) isimli sivil toplum örgütü de 2012 yılında Türkiye ile ilgili bir internet raporu sunmuştur (EDRi, 2012). Bu raporda, sosyal ağlar üzerinde yer alan içerikle ilgili davalar, Sağlık Bakanlığı'nın yanlış bilgiler içerdiği gerekçesiyle 200 web sitesinin filtrelenmesini istemesi, 22 Kasım 2011 tarihinden itibaren uygulamada olan "güvenli internet" uygulamasının yeterince açık olmadığı ve OSCE${ }^{11}$ ülkeleri içinde sadece Türkiye'de böyle bir merkezi filtreleme sisteminin olduğu belirtilerek eleştiriler yöneltilmiştir. Türkiye'de uygulanan merkezi filtreleme sisteminin şeffaf bir şekilde uygulanmaması, benzer şekilde birçok raporda Türkiye aleyhine eleştirilerin odağı haline gelmiştir. Herhangi bir gözetleme ya da sansür yasası olmamasına rağmen, mevcut durumun sansür uygulamasına dönüşmekte olduğu değerlendirilmektedir (Bitso, Fourie ve Bothma, 2012).

Türkiye'de bilgi merkezlerinde uygulanan internet filtreleme yönteminin de diğer $A B$ ülkelerinden farklı olduğu görülmektedir. İngiltere ve Almanya gibi önde gelen Avrupa ülkelerinde, bilgi merkezi yönetiminin kontrolü altında kullanılan yerel filtreleme programları çocukların kullanmakta oldukları bilgisayar terminallerinde ve çocukları korumak amacıyla kullanılmaktadır. Ayrıca, erişim engelleme ve filtreleme uygulamalarının kullanımına ilişkin bir politikanın belirlenmiş olması dikkat çekicidir. Türkiye'de ise, bilgi merkezlerinde kullanılan yerel filtreleme programlarının tüm bilgisayar terminallerinde çocukları korumanın yanı sıra bilişim suçlarını önleme amacıyla da kullanıldığı görülmektedir. Ayrıca diğer bazı AB ülkelerinde de (İtalya, İspanya vb.) olduğu gibi; erişim engelleme ve filtreleme uygulamalarının kullanımına ilişkin bir politikanın bulunmadığı görülmektedir (IFLA, 2010).

\section{Erişimi Engellenen Sitelere Erişim Durumu ve Engelleme Yöntemlerinin Başarısı}

İnternet sitelerinin etkinliğini analiz edebilmek için, web sayfası erişim bilgileri ve ağ trafiği hakkında fikir veren hizmet sağlayıcılar kullanılmaktadır. Web sayfalarına reklam verme vb. amaçlar için yapılan birçok değerlendirme, bu tür web analiz hizmeti sunan sitelerinin yapmış oldukları analizlerin sonrasındaki sıralama puanlarına bakılarak yapılmaktadır. Bu konuda en fazla başvurulan araçlardan biri de "alexa.com" web sayfasıdır. Bu çalışmada da Türkiye üzerinden erişimi engellenen web sayfalarına (engellemeye rağmen) erişim durumunu görebilmek amacıyla, en güvenilir web analiz araçlarından biri olan Alexa'dan faydalanılmıştır. Çalışmadan elde edilen sonuçlar, erişim engellerinin, belirli bir alana erişmeye çalışan kullanıcıları durdurmada başarılı

11 Organization for Security and Cooperation in Europe (OSCE): 56 üyesi bulunan Avrupa Güvenlik ve Işbirliği Teşkilatı (AGIT/OSCE); demokratikleşme, insan haklarına saygı ve şeffaf ekonomi konularında işbirliğini geliştirmek amacıyla kurulmuştur. 
olamadığını göstermektedir. Örneğin 5651 Sayılı Kanun uyarınca katalog suçlar kapsamında yapılan teknik inceleme ve hukuksal değerlendirme sonucunda; "sex. com" internet adresi için, TiB'in 01.04.2011 tarih ve 421.02.00.2011-129032 nolu kararı gereğince idari tedbir uygulanmaktadır (TiB, 2013). Alexa sitesi üzerinden "sex.com" internet sitesinin erişim kayıtları incelendiğinde, Türkiye'nin bu siteye erişim oranının, sitenin erişime engellenmediği ülkelerle aynı seviyelerde olduğu görülmektedir. Site ağ trafiği ile ilgili sıralamada da benzer sonuçlara ulaşılmaktadır. Bu sıralama, sitenin ilgili ülke nazarındaki bilinirliğini ve ne kadar meşhur olduğunu göstermektedir. Sıralama puanına etki eden unsurlar ise, siteye ilgili ülkeden yapılan günlük erişim miktarı ve son 1 ay içinde sayfanın görüntülenme miktarının ortalaması ile elde edilmektedir. Benzer şekilde, Almanya üzerinden hizmet veren bir bahis sitesi olan "tipico.com" isimli internet sitesine 1 Mart 2012 tarihinden itibaren Türkiye'den erişim engellenmektedir (TiB, 2013). Fakat sitenin erişime engellenmesinden bir yıl sonraki Alexa'nın verilerine göre, dünya genelinde Almanya, Portekiz ve Avusturya'dan sonra bu siteye en fazla erişimin Türkiye üzerinden yapılmakta olduğu görülmektedir (Alexa, 2013b). Aynı sitenin erişim engelinden sonra hizmet vermeye başladığı ikinci adresinin (tipico-sportsbetting. com) erişim trafiğine bakıldığında ise, Türkiye'nin \%83.1 oranında ziyaretçi sayısı ile ilk sırada yer aldığı görülmektedir (Alexa, 2013c). Diğer erişimi engellenen popüler bahis sitelerinin (betboo, tempobet vb.) erişim kayıtları analiz edildiğinde de aynı durumun geçerli olduğu görülmektedir. Bu örneklerde erişim yasaklarının erişimi engellemede etkili bir çözüm yolu olmadığı görülmektedir. Ayrıca, erişime engellenen ve özellikle yabancı bir ülkeden hizmet sunan internet sitelerinin, farklı bir isim ile kullanıcılarına ulaşmak için yeni çözümler üretmesi, erişimi engellemek için sadece kullanıcıyı kısıtlamanın yetersiz olduğunu göstermektedir.

Erişim yasaklarının sonuçlarını değerlendirirken, erişim engellemelerinin internet kullanıcıları üzerindeki etkisini gösteren ölçümler de göz ardı edilmemelidir. Özkan ve Arıkan'ın 2009 yılında 138 üniversite öğrencisi üzerinde gerçekleştirmiş olduğu araştırmanın sonucunda, katılımcıların büyük bölümünün devletin interneti kontrolüne karşı oldukları, ebeveynlerin ve öğrenci gruplarının içerik kontrolü ve web erişimi üzerinde daha etkin olmaları gerektiğini düşündükleri görülmektedir. Bununla birlikte, katılımcıların büyük bölümü, müstehcenlik konusunda suç unsuru içeren sitelerin erişime kapatılması gerektiğini düşünmektedirler (Özkan ve Arıkan, 2009). 2011 yılında Tỉ'e gelen 207.550 ihbarın \%78'inin müstehcenlik içeren internet siteleri olması da bu düşünceyi doğrulamaktadır (Aydoğmuş, 2012). Bir başka örnek olarak; "Avrupa Çevrimiçi Çocuklar Projesi" kapsamında yapılan çalışmalar, çocukların internet erişim engellemelerinden nasıl etkilendiklerini izlemeyi sağlayan ve ülkeler arasındaki farklılıkları gösteren önemli kaynaklardır. Avrupa Komisyonu'nun "Güvenli İnternet Programı" kapsamında desteklenen ve 25 Avrupa ülkesinden 9-16 yaş grubu 25.142 çocuk ile 2010 yılında yapılan yüz yüze görüşmelerde riskler, farkındalık ve politik etkilere ilişkin önemli bulgular elde edilmiştir. En az riske maruz kalma oranına sahip üç ülkeden biri olarak görünen Türkiye'nin, aynı zamanda en az faaliyet 
çeşidine sahip iki ülkeden biri olması dikkat çekicidir (EU Kids Online, 2012). Başka bir deyişle, risklerin azaltılmasının, internet olanaklarını ve bilgi davranışını da kısıtladığı görülmektedir. Dünya genelindeki sansür tartışmalarının da aynı yönde olduğu ve özellikle çocuk pornografisi üzerinde hassasiyetin bulunduğu görülmektedir. İnternette erişim engellemelerinin toplumu zararlı içeriklerden korumak için önemli olduğunu düşünenler olsa da, sansür uygulamalarına dönüşen kısıtlamaları destekleyenlerin oranı sadece \%12'dir (Debade.org, 2013).

\section{Engellenen Sitelere Erişim ve Hukuki Sorumluluk}

Erişimi engellenen sitelere girmek için, internet erişim ayarları üzerinde birtakım değişikliklerin (DNS, Proxy vb.) yapılması gerekmektedir. Bu değişiklik, bilgisayar kullanıcısının internete çıkarken ve eriştiği siteye ulaşıncaya kadar olan süreçte izleyeceği yolu seçmesi işlemidir. Başka bir ifadeyle, kullanıcının, verilerinin internet ortamında üzerinden geçeceği yönlendirici ve sunucular hakkında kendi iradesini kullanmasıdır. Sadece kişisel özgürlükler açısından bakıldığında, engellenen bir siteye erişim için izlenen yöntemlerden dolayı bir kullanıcının tercih hakkını kullandığı ve bunu engellemek için herhangi bir hukuksal düzenleme olmadığı söylenebilir. Ancak, konunun hukuksal yönü de mevcut düzenlemeler çerçevesinde değerlendirilmelidir.

Erişimi engellenen ya da müstehcen içeriğe sahip bir internet sitesine girilmesi, erişilen sitenin içeriğine ve bu site ile ilgili olarak verilen mahkeme kararına bağlı olarak değerlendirilebilir. Buna göre sorunun iki farklı boyutu olduğu görülmektedir. Bunlardan biri, verilen mahkeme kararına rağmen bir fiilin gerçekleştirilmesidir. Mahkeme kararı ile erişime engellenmiş olan bir içeriğe çeşitli teknik yöntemler (Proxy, DNS vb.) kullanılarak erişim sağlamak ve bu sitelerden içerik indirmek suç teşkil etmektedir. Diğer boyutu ise, site içeriğinin yasal düzenlemelerde de açıkça ifade edilen uygunsuz içeriği (çocukların istismarı vb.) barındırması, fakat henüz siteye erişimin engellenmemiş olmasıdır. Erişime yasaklanmamış bir site içeriğinde çocuk pornografisi vb. olup olmadığının siteye girmeden önce anlaşılabilmesi çoğu zaman mümkün değildir. Bununla birlikte, bilgisayar virüslerinin de bu tür istem dışı işlemler gerçekleştirmesi sık rastlanılan bir durumdur. Bu nedenle, uygulamada zararlı içeriğe sahip sitelere erişimden dolayı yasal işlem yapılmamaktadır. Fakat bu tür sitelerden dosya indirmeyi alışkanlık haline getirmiş olma, çocukların kullanıldığı müstehcen yayınları üretme, çoğaltma, satma, nakletme, bulundurma, depolama ve başkalarının kullanımına sunma gibi davranışlarla ilgili olarak, TCK'nın 226. maddesinde yer alan hükümlerin gerektirdiği adli işlemler yapılmaktadır.

TCK'nun 226/3. Maddesi gereğince Yargıtay 5. Ceza Dairesi tarafından 1 Kasım 2007 tarihinde alınan 2007/6967 numaralı karar (Hukuk Bilgi Bankası, 2007), çocuk pornografisi hakkındaki sınırların çizilmesi konusunda belirleyici ve 5651 Sayılı Kanunun uygulanmasındaki soru işaretini ortadan kaldırması açısından açıklayıcı olması yönüyle önemlidir. Kararda, "çocuk pornografisine ilişkin çok sayıda resim ve video kaydını bilgisayar sistemi vasıtasıyla temin edip bilgisayarda sistematik biçimde 
depolama ve bulundurma" fiilinin kişisel amaçlı dahi olsa TCK 226/3. maddesine uyan suçu oluşturduğu açıkça belirtilmiştir. Ayrıca bu kararda, Türkiye'nin de taraf olduğu Çocuk Haklarına Dair Sözleşménin 34/c maddesi (TBMM, 1994), Uluslararası Çalışma Örgütü'nce kabul edilen 182 sayılı Kötü Şartlardaki Çocuk İşçiliğinin Yasaklanması ve Ortadan Kaldırılmasına İlişkin Acil Önlemler Sözleşmesi'nin 1 ve 3/b maddeleri (4623 Sayılı Kanun, 2001) ve Çocuk Haklarına Dair Sözleşmeye Ek Çocuk Satışı, Çocuk Fahişeliği ve Çocuk Pornografisi ile İlgili İhtiyari Protokolıün 1, 2/c, 3/1, 3/1-c ve 3/3. Maddelerine (4755 Sayılı Kanun, 2002) atıfta bulunularak, bu konuda dikkate alınan hukuk kaynakları işaret edilmiştir.

Engellenen internet sitelerine girmeye ilişkin olarak çelişkili gibi görünen bir başka konu kumar oynanan sitelerin durumudur. Türkiye'de kumar oynanması için yer ve imkân sağlanması, TCK'nın 228. maddesi (Türk Ceza Kanunu, 2004) ve 7258 sayılı Futbol ve Diğer Spor Müsabakalarında Bahis ve Şans Oyunları Düzenlemesi Hakkında Kanunu'nun 5. maddesi (7258 Sayılı Kanun, 1959) kapsamında suç olarak düzenlenmiştir. Bu tür sitelerin yurt içinde olması halinde içeriğin yayından kaldırılması, yurt dışında olması halinde ise erişimin engellenmesi yöntemi uygulanmaktadır. Fakat kumar oynamaya ilişkin TCK'da ya da 7258 Sayılı Kanunda herhangi bir düzenleme bulunmamaktadır. Bu nedenle, bu tür sitelere erişim ve kumar oynama ile ilgili fiiller, Kabahatler Kanunu'nun 34. maddesi $^{12}$ çerçevesinde değerlendirilmektedir.

Herhangi bir internet sitesi mahkeme ya da TiB tarafından erişime engellendiğinde; engelleme kararı hakkında bilgi veren sayfa ile karşılaşılmaktadır. Ancak bu uygulamanın erişimi engellenen tüm internet siteleri için yapılmaması, kullanıcılarda servis hatası nedeniyle bağlanılamadığı algısını oluşturmakta ve alternatif yöntemler ile sayfaya erişim sağlamaya yönlendirebilmektedir. Kullanıcının erişilemeyen her sayfayı Tỉ sorgulama ekranından sorgulama sorumluluğu bulunmadığı ve yasaklanan siteler kullanıcılara resmi kurumlar aracılığıyla duyurulmadığı için, bu konuda sorumlu olamayacağı değerlendirilmektedir. Erişime engellenen her internet sitesine ilişkin bilgi sayfasının bulunması, hatta bu sayfada kararın hangi kanun maddeleri gereğince alındığının açıklanması önemlidir. Böylece, kullanıcı alternatif yollarla siteye girmesi halinde nasıl bir durum ile karşı karşıya kalacağı hakkında bilgi sahibi olacaktır.

\section{Değerlendirme ve Sonuç}

Devletlerin toplumları ve özellikle çocukları internet ortamında bulunan zararlı içeriğe karşı koruma yükümlülüğü bulunmaktadır. Bu nedenle, dünya genelinde internet içeriğinin düzenlenmesi ile ilgili hukuksal düzenlemeler yapılmakta ve etkin bir şekilde uygulanmaktadır. Dünya genelinde çocuk pornografisi gibi zararlı internet içeriğine karşı mücadelenin yaygın olduğu ve uluslararası işbirliğinin sağlanması için

12 Kabahatler Kanunu Madde 34 - (1) Kumar oynayan kişiye, yüz Türk Lirası idarî para cezası verilir. Ayrıca, kumardan elde edilen gelire el konularak mülkiyetin kamuya geçirilmesine karar verilir. 
çalışmaların arttığı görülmektedir. AB'de zararlı içeriğe karşı filtreleme yöntemleri 15 yıldan beri kullanılmaktadır. Bu yönüyle bakıldığında; 5651 Sayılı İnternet Kanunu için geç kalınmış bir hukuksal düzenleme olduğu dahi söylenebilir. 5651 Sayılı Kanun'da, içerik denetiminin nasıl ve hangi kurumlar tarafından yapılacağı düzenlenmiştir. 5651 Sayılı Kanun kapsamında yer alan suçların internet ortamında işlenmesinin önlenmesi, uluslararası kuruluşlarla gerekli koordinasyonun sağlanmass, ihbarların değerlendirilmesi, içeriğin izlenmesi ve önlemlerin alınması görevi Tỉße verilmiştir. Ancak mevcut hukuki düzenlemenin uygulanması ile TíB'in çocukların korunması konusunda oynadığı rol, ailelerin koruma önceliğinin önüne geçmektedir. Çocukların güvenli internet kullanımı için dünya genelinde gösterilen hassasiyet Türkiye'de de önemsenmeli ve gerekli önlemler alınmalıdır. Fakat temel erişim kısıtlama yöntemleri ile bu sorunu çözmeye çalışmak, yeterli korumayı sağlamamakla birlikte, sansür uygulamasına dönüşebilmektedir. Devletin korumacılık konusunda uygulamakta olduğu yöntemin, hukuki düzenlemelerde yapılacak değişikliklerle daha demokratik bir şekilde gerçekleştirilmesi mümkündür. Demokratik toplumlarda olduğu gibi, erişim engellemelerinin sansüre dönüşmemesi için uygulanan yöntemlerin daha açık olmasına ve alınan kararlara toplumsal katılımın sağlanmasına özen gösterilmelidir.

Türkiye'de de dünya genelinde olduğu gibi hukuksal düzenlemeler çerçevesinde erişim engellemeleri yapılmaktadır. Fakat hukuksal düzenlemelerde kurumlara verilen yetkilerin sınırı ve katalog suçların hangi sınırlar içinde gerçekleşmiş sayılacağı açık olmadığı için uygulamanın doğruluğu ve güvenilirliği tartışmalıdır. Erişime engellenen sitelerle ilgili olarak yetkili kurumların bildirimde bulunmaması, engellenen sitelerin merak uyandırmaması açısından olumlu karşılanabilir. Ancak istatistiki bilgilerin verilmemesi ve engellenen sitenin hangi gerekçe ile engellendiği bilgisinin ilgili sayfada yer almaması, uygulamada yanlışlar olduğu ya da Türkiye'nin sansür uygulamaları konusunda kaygılarının olduğu görünümünü vermektedir. Bu durum, uygulamada yanlışlıklar olmasa dahi, Türkiye'nin "gözetim altındaki ülke" sınıfında kalması için yeterli bir neden olarak görülmektedir. İnternet sitelerine erişim engelleme ölçütlerinin açık olarak belirlenerek engelleme ile sansür arasındaki ayrımın fark edilir hale gelmesi ve devletin herkesin erişim sağlayabildiği internet sitelerini takip etmesinin özgürlüğe engel teşkil eden yönünün bulunmadığı bilincinin oluşturulması önem taşımaktadır. Türkiye'de yaklaşık 30.000 internet sitesinin erişime kapatılmış olması da sansür uygulaması yapıldığının göstergesi değildir. Aynı gerekçelerle dünya genelinde filtreleme yöntemlerinin kullanıldığı aşikârdır. Bu konuda dikkat edilmesi gereken nokta, zararlı içeriğin bulunduğu sayfanın filtrelenmesi yerine, demokratik toplumların asla benimsemeyeceği bir yöntem ile tüm siteye erişimin engelleniyor olması ve engellenen sitelerin büyük bölümünün mahkeme onayına sunulmamasıdır. TíB'in zararlı içeriğe sahip internet sitelerini tespit etme ve erişim engelleme sorumluluğu, mümkün olduğu ölçüde teknik imkânlar geliştirilerek sadece zararlı içeriğin bulunduğu sayfanın filtrelenmesi ile sınırlandırılmalı, içeriğinin tamamının hukuka aykırı olması halinde site erişime kapatılmalıdır. 
İnternet ortamında bulunan zararlı içeriğin yayından kaldırılması dışındaki tüm erişim engelleme uygulamaları, erişimi zorlaştırmanın ötesine geçemeyen tedbirlerdir. Her geçen gün katlanarak artan zararlı içeriğin tamamını tespit etmek ve engellemek, bir kurum ya da bir devletin tüm imkânlarını seferber etmesi halinde dahi mümkün değildir. Ayrıca erişime engellenen internet siteleri, farklı bir isim ile yeniden açılarak faaliyetlerine devam etmektedirler. Bununla beraber, engellenen sitelere erişmek isteyen kullanıcıların alternatif yollar kullandığı ve bu sitelere olan erişim miktarında azalma olmadığı görülmektedir. Bu nedenle, içeriğin yayından kaldırılması kararları ve mahkeme tarafından onaylanmış erişim engellemelerine ek olarak toplumu ve özellikle çocukları korumak için en etkili çözüm güvenli internet projeleri içinde yer alan eğitim ve bilinçlendirme çalışmalarına daha fazla ağılık verilmesidir. Sağlık Bakanlığı'nın uygulamakta olduğu gibi kamu spotu vb. uyarıcı araçların kullanımının toplumu yanlış yönlendiren zararlı internet sitelerin etkisinin azaltılması ve kendiliğinden yayından kalkmasında daha etkili olduğu değerlendirilmektedir. Eğitim düzeyinin yükseltilmesi ve kültürel yapının geliştirilmesi bireysel bilinçlenmeyi artırarak zararlı içerikten korunmayı sağlayacağı gibi, otoriteyi sağlamak amacıyla uygulamada yapılacak yanlışlara eleştirel bakış açısı ile bakabilme yeteneği de kazandıracaktır.

İnternet, her geçen gün bireysel işlemlerin daha fazla yapıldığı ve bilgi yönetiminin kişisel olarak çok daha yoğun gerçekleştiği bir ortama dönüşmektedir. Her bireyin özel bir cep telefonu olduğu gibi bireyi takip eden ve dünyanın herhangi bir yerinde herhangi bir terminalden bağlantı kurduğu anda kaldığı yerden devam edebilmesini sağlayacak internet servisine olan ihtiyaç da artmaktadır. Günümüzde internet abonesini tanıyan servis sağlayıcıların ötesinde, dijital kimlik tanıma sistemi kullanarak internet kullanıcısını tanıyan çözümlerin üretilmesi üzerinde daha yoğun olarak düşünülmeye başlanmıştır. Bu tür çözümlerin hayata geçirilmesiyle, sadece çocukları ve gençleri korumakla sınırlı kalmayıp, aynı zamanda kullanıcıların kişisel bilgileri üzerinde kontrolü ele aldığı güvenli internet erişimi ve e-ticaret imkânı da sağlanabilecektir (Cavoukian, 2008). Dijital kimlik tanıma sistemleri, internet kullanıcısının kendisine ait bilginin sınıflandırılması, kullanılması, gizliliğinin belirlenmesi gibi yönetimsel işlemleri kendi özgür iradesi ile yapabilmesine olanak sağlamaktadır. Aynı zamanda, kullanıcının yaş ve kimlik bilgisi sistem tarafından tanınarak, hukuksal düzenlemelerin güvenli ve tam olarak uygulanabilirliği sağlanabilecek ve bilişim suçlarına yönelik önleyici tedbir olarak da kullanılabilecektir. Bu tür uygulamanın hayata geçirilebilmesi için iki ön şartın yerine getirilmesi gerekmektedir. Öncelikle, dijital kimlik kullanımı ile elde edilen bilgilerin korunmasının sağlanabilmesi için, uygulanabilir ve uyulmaması halinde önemli yaptırımları bulunan kişisel verileri koruma kanununun hayata geçirilmesi gerekmektedir. İkinci olarak, servis sağlayıcıların gerekli yatırımı yaparak belirlenen standarda uygun teknik altyapıyı oluşturması ve her kullanıcının zorunlu olarak dijital kimliği kullanması sağlanmalıdır. Bu yapıdaki kimlik kontrolü, cep telefonlarının kullanımında kullanılan kimlik doğrulama sisteminden daha karmaşık değildir. Cep telefonu kullanımına ilişkin görüşme, yer ve konum bilgileri de servis sağlayıcı 
tarafından izlenebilmekte ve kullanıcı ile servis sağlayıcının belirlemiş olduğu arama kısıtlamaları kullanıcı bazında uygulanmaktadır. Kişisel verilerin ve gizliliğin yasal güvence altına alınması şartıyla; adli işlemlerde suçun ve suçlunun tespitinde de mobil iletişim teknolojisinde olduğu gibi, dijital kimlik tanıma sistemi kullanımının büyük kolaylık sağlayacağı değerlendirilmektedir.

Toplum ahlakını olumsuz etkileyebilecek sınırsız düşünce özgürlüğü internet ortamında da kabul edilebilir değildir. Toplumun her kesiminin üzerinde uzlaşmış olduğu çocuk pornografisi gibi zararlı içeriğin bulunduğu sayfalara yönelik erişim engellemeleri birçok ülkede olduğu gibi Türkiye'de de sansür uygulaması olarak değerlendirilmemektedir. Ancak yasal düzenlemelerdeki eksiklikler nedeniyle erişim kapatma kararlarının sansür uygulamasına dönüştüğü konusunda kaygılar artmaktadır. Hukuksal düzenlemeler, alınan erişim engelleme kararları, Yargıtay kararları ve uygulama sonucunda amaçlanan hedefe ulaşılabilme durumunun irdelendiği bu çalışmada elde edilen verilere bağlı olarak şu noktaların ön plana çıktığı ve tekrar gözden geçirilmesi gerektiği düşünülmektedir:

$\diamond$ Müstehcenlik kavramının belirsiz olması, katalog suçların dışındaki suçlarla nasıl mücadele edileceğinin belirsizliği, zararlı içeriğin engellenmesi yerine tüm siteye erişimin engellenmesi, site sahibine savunma hakkı tanınmaması ve kapatma ile ilgili bilgi verilmemesi, 5651 Sayılı Kanun içinde yeniden gözden geçirilmesi gereken ve Türkiye'nin sansür konusunda sicilini olumsuz etkileyen alanları oluşturmaktadır.

$\diamond \quad$ Yurt dışında bulunan zararlı içeriğe sahip internet siteleri ile ilgili olarak doğrudan erişime engelleme kararı almak yerine, sadece zararlı içeriğin yayından kaldırılması ya da ilgili sayfanın Türkiye'den görüntülenemeyecek şekilde filtrelenmesi en akılcı çözümdür. Tüm sitenin erişime kapatılması, diğer ülkelerin bu zararlı içeriğe erişimine engel olmadığı gibi sadece Türkiye'deki kullanıcıları cezalandırmakta ve alternatif erişim yöntemlerinin kullanılmasını yaygın hale getirmektedir.

$\diamond \quad$ Engellenecek zararlı içeriğin tespit edilmesi konusunda aşırı duyarlı olunmaması ve toplumsal katılımın sağlanması daha demokratik ve etkin önlemlerin alınmasını sağlayacaktır. Ayrıca 5651 Sayılı Kanun'da yer alan ve TiB ile işbirliği içinde çalışması beklenen "Internet Kurulu"nun etkinliği artırılmalı ve çalışmaların toplum tarafından izlenebilmesi sağlanmalıdır.

$\diamond \quad$ Erişime engellenen sitelerin Türkiye'den erişim istatistikleri incelendiğinde erişim engelleme politika ve uygulama yöntemlerinin amacına ulaşmada başarısız olduğu görülmüştür.

$\diamond$ Saydam olmayan, kullanıcıların desteklemediği ve katılım sağlamadığı uygulamalardan vazgeçilerek, kişiye özel filtrelemenin uygulanmasına imkân sağlayacak teknik altyapının servis sağlayıcılar tarafından oluşturulması zorunlu hale getirilmelidir. Her internet kullanıcısının seçmiş olduğu güvenli internet filtreleme paketi içeriğinde değişiklik yapabilmesi ve böylece kendi özelleştirilmiş filtreleme paketini oluşturarak kendi güvenliğinden sorumlu olması sağlanmalıdır. 
$\diamond$ Çocukların korunmasında asıl görev ve sorumluluk ailelerindir. Devletlerin çocukları ve aileleri koruma önceliği, ağırlıklı olarak eğitim ve bilinçlendirme projelerinin yürütülmesi üzerine olmalıdır.

$\diamond$ Güvenli internet erişim projeleri içinde, herkese ulaşılabilen televizyon vb. iletişim araçları üzerinden de eğitim ve bilinçlendirme çalışmalarına ağırlık verilmelidir. Sadece erişim engelleme yöntemleri ile zararlı içerikten korunmak mümkün değildir.

\section{Kaynakça}

26716 Sayılı Yönetmelik. (2007). Internet Ortamında Yapılan Yayınların Düzenlenmesine Dair Usul ve Esaslar Hakkında Yönetmelik. 20 Mart 2013 tarihinde http://www.mevzuat.adalet.gov.tr/ $\mathrm{html} / 27666 \mathrm{html}$ adresinden erişildi.

4623 Sayılı Kanun. (2001). Kötü Şartlardaki Çocuk Iş̧̧iliğinin Yasaklanması ve Ortadan Kaldırılmasına İlişkin Acil Önlemler Sözleşmesinin Onaylanmasının Uygun Bulunduğuna Dair Kanun. 12 Nisan 2013 tarihinde http://www.tbmm.gov.tr/kanunlar/k4623.html adresinden erişildi.

4755 Sayılı Kanun. (2002). Çocuk Haklarına Dair Sözleşmeye Ek Çocuk Satışı, Çocuk Fahişeliği ve Çocuk Pornografisi ile Illgili ihtiyari Protokolün Onaylanmasının Uygun Bulunduğu Hakkında Kanun. 13 Nisan 2013 tarihinde http://www.tbmm.gov.tr/kanunlar/k4755.html adresinden erişildi.

4756 Sayılı Kanun. (2002). Radyo ve Televizyonların Kuruluş ve Yayınları Hakkında Kanun, Basın Kanunu, Gelir Vergisi Kanunu ile Kurumlar Vergisi Kanununda Değişiklik Yapılmasına Dair Kanun. 24 Mart 2013 tarihinde http://www.tbmm.gov.tr/kanunlar/k4756.html adresinden erişildi.

5187 Sayılı Kanun. (2004). 5187 Sayılı Basın Kanunu. 28 Nisan 2013 tarihinde http://www.tbmm. gov.tr/kanunlar/k5187.html adresinden erişildi.

5651 Sayılı Kanun. (2007). Internet Ortamında Yapılan Yayınların Düzenlenmesi ve Bu Yayınlar Yoluyla Işlenen Suçlarla Mücadele edilmesi Hakkında Kanun. 20 Mart 2013 tarihinde http:// www.mevzuat.adalet.gov.tr/html/27511.html adresinden erişildi.

5680 Sayılı Kanun. (1950). 5680 Sayılı Basın Kanunu. 24 Mart 2013 tarihinde http://www.hukuki. net/kanun/5680.13.text.asp adresinden erişildi.

6112 Sayılı Kanun. (2011). Radyo ve Televizyonların Kuruluş ve Yayın Hizmetleri Hakkında Kanun. 23 Mart 2013 tarihinde http://www.mevzuat.gov.tr/MevzuatMetin/1.5.6112.pdf adresinden erişildi.

7258 Sayılı Kanun. (1959). Futbol ve Diğer Spor Müsabakalarında Bahis ve Şans Oyunları Düzenlemesi Hakkında Kanun. 20 Nisan 2013 tarihinde http://www.mevzuat.gov.tr/MevzuatMetin/1.3.7258. pdf adresinden erişildi.

Akdeniz, Y. (2001). Internet content regulation: UK government and the control of internet content. Computer Law \& Security Report, 17(5), 303-317. 4 Nisan 2013 tarihinde erişildi.

Alexa. (2013a). Top sites in Turkey. 12 Nisan 2013 tarihinde http://www.alexa.com/topsites/ countries/TR adresinden erişildi.

Alexa. (2013b). Visitors by Country for Tipico.com. 5 Nisan 2013 tarihinde http://www.alexa.com/ siteinfo/tipico.com\# adresinden erişildi. 
Alexa. (2013c). Visitors by Country for Tipico-sportsbetting.com. 5 Nisan 2013 tarihinde http://www. alexa.com/siteinfo/tipico-sportsbetting.com\# adresinden erişildi.

Al-Saqaf, W. (2010). Internet censorship challenged: How circumvention technologies can effectively outwit governments attempts to filter content. Alkasir, a case study. C. Strand. Increasing transparency and fighting corruption through ICT: Empowering people and communities içinde (s. 71-93). Stockholm: Spider.

Aydoğmuş, A. (2012). En çok müstehcen siteler ihbar ediliyor. 7 Nisan 2013 tarihinde http://www. teknolojioku.com/haber/guncel/en-cok-mustehcen-siteler-ihbar-ediliyor.html adresinden erişildi.

Bitso, C., Fourie, I. ve Bothma, T. (2012). Trends in transition from classical censorship to Internet censorship: Selected country overviews. Pretoria: IFLA.

Blight, G., Rininsland, ÆE., Rogers, S., ve Torpey, P. (2012). Howopen is your internet? An interactive map. 21 Nisan 2013 tarihinde http:/www.guardian.co.uk/technology/datablog/interactive/2012/ apr/16/web-filtering-censorship adresinden erişildi.

BM. (2008). UN GA Resolution 2008: Section on Violence Against Children. 25 Nisan 2013 tarihinde http://www.crin.org/law/Instrument.asp?!nstID=1380 adresinden erişildi.

Bothma, T. (2010). IFLA World Report 2010. Netherlands: IFLA.

BTK. (2011). Güvenli Internet Hizmetine Ilişkin Usul ve Esaslar. 24 Mart 2013 tarihinde http://btk.gov. tr/mevzuat/kurul_kararlari/dosyalar/2011\%20DK-14-461.pdf adresinden erişildi.

BTK. (2012). Güvenli internet hizmeti nedir? 24 Mart 2013 tarihinde http://www.guvenlinet.org.tr/ tr/menu/21-Guvenli_Internet_Hizmeti\%C2\%AE_Nedir .html adresinden erişildi.

Cavoukian, A. (2008). Privacy in the clouds. Privacy and digital identity: Implications for the internet. içinde Toronto: Information and privacy commissioner of Ontario.

CIPA. (2000). Children's Internet Protection Act. 20 Nisan 2013 tarihinde http://www.ala.org/ advocacy/sites/ala.org.advocacy/files/content/advleg/federallegislation/cipa/cipatext.pdf adresinden erişildi.

CRIN. (2000). Optional Protocol to the UN Convention on the Rights of the Child on the sale of children, child prostitution and child pornography. 10 Nisan 2013 tarihinde http://www.crin.org/law/ instrument.asp?!nst|D=1002 adresinden erişildi.

Debade.org. (2013). History and debate of internet censorship. 7 Nisan 2013 tarihinde http://www. debate.org/internet-censorship/ adresinden erişildi.

EDRi. (2012). Turkey: Internet report on digital rights 2012. 27 Mart 2013 tarihinde http://www.edri. org/book/export/html/3115 adresinden erişildi.

Engelliweb. (2013). Erişime engellenen web siteleri. 27 Mart 2013 tarihinde http://engelliweb.com/ kategoriler/ adresinden erişildi.

EU Kids Online. (2012). The EU Kids Online survey. 7 Nisan 2013 tarihinde http://www2.Ise.ac.uk/ media@Ise/research/EUKidsOnline/EU\%20Kids\%20II\%20(2009-11)/EUKidsExecSummary/ UKExecSum.pdf adresinden erişildi. 
European Commission. (2001). Convention on Cybercrime. 10 Nisan 2013 tarihinde http:// conventions.coe.int/treaty/en/treaties/html/185.htm adresinden erişildi.

European Council. (2012). Council conclusions of 26 November 2012 on the European strategy for a Better Internet for Children. 4 Nisan 2013 tarihinde http://eur-lex.europa.eu/LexUriServ/ LexUriServ.do?uri=OJ:C:2012:393:0011:0014:EN:PDF adresinden erişildi.

European Parliament. (1999). Decision No 276/1999/EC of the European Parliament and of the Council of 25 January 1999 adopting a multiannual Community action plan on promoting safer use of the Internet by combating illegal and harmful content on global networks. 5 Nisan 2013 tarihinde http://eur-lex.europa.eu/LexUriServ/LexUriServ.do?uri=CELEX:31999D0276:EN:HTML adresinden erişildi.

European Parliament. (2003). Amending Decision No 276/1999/EC adopting a multiannual Community action plan on promoting safer use of the Internet by combating illegal and harmful content on global networks. 4 Nisan 2013 tarihinde http://eur-lex.europa.eu/LexUriServ/ LexUriServ.do?uri=OJ:L:2003:162:0001:0004:EN:PDF adresinden erişildi.

European Parliament. (2005). Establishing a multiannual Community Programme on promoting safer use of the Internet and new online technologies. 4 Nisan 2013 tarihinde http://eur-lex.europa. eu/LexUriServ/LexUriServ.do?uri=OJ:L:2005:149:0001:0013:EN:PDF adresinden erişildi.

European Parliament. (2011). Directive 2011/92/EU of the European Parliament and of the Council of 13 December 2011 on combating the sexual abuse and sexual exploitation of children and child pornography, and replacing Council Framework Decision 2004/68/JHA. 4 Nisan 2013 tarihinde http://eur-lex.europa.eu/LexUriServ/LexUriServ.do?uri=OJ:L:2011:335:0001:0014:EN:PDF adresinden erişildi.

Google. (2012). Şeffaflı raporu. 14 Nisan 2013 tarihinde http://www.google.com/ transparencyreport/removals/government/TR/?by=product\&p=2012-06 adresinden erişildi.

Howtobypassinternetcensorship.org. (2011). Bypass internet censorship quickstart. 20 Nisan 2013 tarihinde http://www.howtobypassinternetcensorship.org/files/bypass-internet-censorshipquickstart.pdf adresinden erişildi.

Hukuk Bilgi Bankası, 2007/9856 (T.C. Yargıtay Başkanlığı. 01 Ekim 2007). 10 Nisan 2013 tarihinde http:// www.hukukturk.com/fractal/hukukTurk/pages/findKararDetail_n.jsp?\&pKunye=Yarg\%FDtay\%20 5.\%20\%20Ceza\%20Dairesi\%20-\%20Esas\%20No:\%202007/9856\%20-\%20Karar\%20No\%20: 2007/6957\%20\%20-\%20Tarih:\%2001/10/2007\&pTopHtml=\%3Ctable\%20border=0\%20 cellspacing $=0 \% 20$ cellp adresinden erişildi.

Hukuk Bilgi Bankası, 2012/6581 (T.C.Yargıtay Başkanlığı. 13 Haziran 2012). 10 Nisan 2013 tarihinde http:// www.hukukturk.com/fractal/hukukTurk/pages/findKararDetail_n.jsp?pKunye=Yarg\%FDtay\%20 4.\%20\%20Hukuk\%20Dairesi-\%20Esas\%20No:\%202012/6581\%20-\%20Karar\%20No\%20: 2012/10331\%20-\%20\%20-\%20Tarih:\%2013/06/2012\&\&pTopHtml=\%3Ctable\%20border=0\%20 cellspacing $=0 \% 20$ ce adresinden erişildi.

IFLA. (2010). IFLA World Report 2010. 27 Mart 2013 tarihinde http://www.ifla-world-report.org/ cgi-bin/static.ifla_wr.cgi?dynamic $=1 \& d=$ ifla_wr_browse\&page $=$ query\&interface $=$ map adresinden erişildi. 
Jones, B. M. (1999). Libraries, access and intellectual freedom: Developing policies for public and academic libraries. Chicago: American Library Association.

Malley, I. (1990). Censorship and Libraries. London: Library Association Publishing.

Netcraft. (2013). April 2013 web server survey. 15 Nisan 2013 tarihinde http://news.netcraft.com/ archives/2013/04/02/april-2013-web-server-survey.html adresinden erişildi.

NTVMSNBC. (2011). Şok eden 'sansür' listesi! 20 Mart 2013 tarihinde http://www.ntvmsnbc.com/ id/25207341/ adresinden erişildi.

OCLC. (2010). Perceptions of Libraries, 2010: Context and Community. Dublin: OCLC Online Computer Library Center.

OpenNet. (2010). Country profiles: Turkey. 20 Nisan 2013 tarihinde http://opennet.net/sites/ opennet.net/files/ONI_Turkey_2010.pdf adresinden erişildi.

Oppenheim, C. ve Smith, V. (2004). Censorship in libraries. Information Services \& Use, 24, 159-170.

OSCE. (2010). Freedom of expression on the internet. Astana: Organization for Security and Cooperation in Europe.

Oxford. (1968). Oxford Latin dictionary. London: Oxford University Press.

Özkan, H. ve Arıkan, A. (2009). Internet censorship in Turkey: University students' opinions. World Journal on Educational Technology, 1(1), 46-56.

Prabhat. (2011). Differance between censorship and restriction. 7 Nisan 2013 tarihinde http://www. differencebetween.net/language/words-language/difference-between-censorship-andrestrictions/ adresinden erişildi.

RWB. (2012). Internet enemies report 2012. 26 Mart 2013 tarihinde http://en.rsf.org/IMG/pdf/ turkiye_2012-2.pdf adresinden erişildi.

Singh, K. (2013). How many wesites are there on the internet as of now. 13 Nisan 2013 tarihinde http://loyfly.com/how-many-websites-are-there-on-the-internet-as-of-now/ adresinden erişildi.

Stone, D. (2012). 2011-2012 state legislation. 28 Nisan 2013 tarihinde http://www.ala.org/ offices/sites/ala.org.offices/files/content/oif/ifgroups/stateifcchairs/stateifcinaction/state_ lege_2012_AC.pdf adresinden erişildi.

TBMM. (1994). Çocuk Haklarına Dair Sözleşme. 12 Nisan 2013 tarihinde http://www.tbmm.gov.tr/ komisyon/insanhaklari/pdf01/137-160.pdf adresinden erişildi.

T.C. Başbakanlık. (2001). Radyo ve Televizyonların Kuruluş ve Yayınları Hakkında Kanun, Basın Kanunu, Gelir Vergisi Kanunu ile Kurumlar Vergisi Kanununda Değişiklik Yapılmasına Dair Kanun Tasarısı ve Anayasa Komisyonu Raporu. 23 Mart 2013 tarihinde https://www.google.com.tr/ url?sa $=t \& r c t=j \& q=\& e s r c=s \&$ source $=$ web $\& c d=1 \& c a d=r j a \& v e d=0 C C 0 Q F j A A \& u r l=h t t p \% 3 A \%$ 2F\%2Fbt-stk.org.tr\%2Frtuk-meclis.doc\&ei=2tRNUb_tN8OfO7HygOAH\&usg=AFQjCNEETbx f8jABjsUFmvPqlqevnkPj0Q\&sig2=cymZF5D67g-H_0q9xuachw\&bvm=bv.44158598,d.ZWU adresinden erişildi.

T.C. Başbakanlık. (2007). Internet Ortamında Yapılan Yayınların Düzenlenmesine Dair Usul ve Esaslar Hakkında Yönetmelik. 13 Nisan 2013 tarihinde http://www.resmigazete.gov.tr/ eskiler/2007/11/20071130-6.htm adresinden erişildi. 
T.C. Cumhurbaşkanlığı. (2001). 4676 sayılı Radyo ve Televizyonların Kuruluş ve Yayınları Hakkında Kanun, Basın Kanunu, Gelir Vergisi Kanunu Ille Kurumlar Vergisi Kanununda Değişiklik Yapılmasına Dair Kanun ve Bir Daha Görüşülmek Üzere Geri Gönderme Tezkeresi ve Anayasa Komisyonu Raporu. 23 Mart 2013 tarihinde http://www.tbmm.gov.tr/sirasayi/donem21/yil01/ss850m. htm adresinden erişildi.

TiB. (2012). 5651 Sayılı Yasa Hakkında. 20 Mart 2013 tarihinde http://www.tib.gov.tr/tr/trmenu-28-5651_sayili_yasa_hakkinda.html adresinden erişildi.

TiB. (2013). Erişimin engellenmesi tedbiri istatistikleri. 13 Nisan 2013 tarihinde http://www. guvenliweb.org.tr/istatistikler/files/erisimengellemeistatistik.pdf adresinden erişildi.

TiB. (2013). Telekomünikasyon Illetişim Başkanlığı Sorgulama Ekranı. 6 Nisan 2013 tarihinde http:// eekg.tib.gov.tr/ adresinden erişildi.

Treble, P. (2008). China aims to clean up the Internet. Maclean's, 122(1).

Türk Ceza Kanunu. (2004). 5237 Sayılı Türk Ceza Kanunu. 10 Nisan 2013 tarihinde http://www. tbmm.gov.tr/kanunlar/k5237.html adresinden erişildi.

Türk Dil Kurumu. (2006). Güncel Türkçe sözlük. Ankara: Türk Dil Kurumu. 